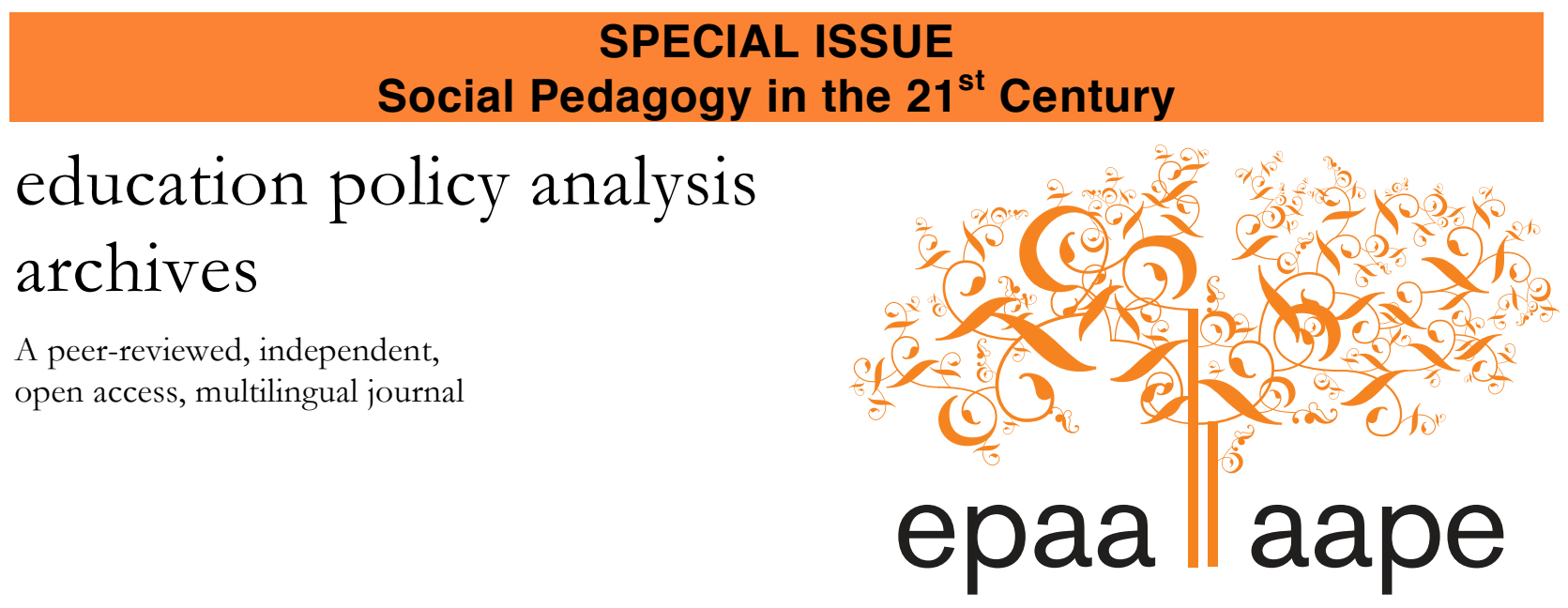

Arizona State University

\title{
Transitions in a life-world: Looking backward and forward after forty-five years of social pedagogical research and teaching in Leuven
}

\author{
Danny Wildemeersch \\ Leuven University \\ Belgium
}

Citation: Wildemeersch D. (2013). Transitions in a life-world: Looking backward and forward after forty-five years of social pedagogical research and teaching in Leuven. Education Policy Analysis Archives, 21(38). Retrieved [date], from http://epaa.asu.edu/ojs/article/view/1313. This article is part of EPAA/AAPE's Special Issue on Social Pedagogy in the 21 st Century, Guest Co-Edited by Dr. Daniel Schugurensky and Michael Silver.

\begin{abstract}
The paper presents the author's reflection on research and teaching over a period of 45 years in a social pedagogy program in the Leuven University (Belgium). While the case is interesting in its own right, it holds broader significance for its contribution to understanding developments in education, adult and community education and social work both in disciplinary terms and regarding practice. It presents the theoretical sources of inspiration from diverse linguistic, cultural, policy and academic contexts. The chronology is organized in four periods marked by turning points that were influenced by internal and external events. The first phase is the pioneering phase. The second is the crisis and recovery phase. The third is the multiplicity phase, and the last phase is that of reinvention. The paper also reflects on some of the major themes and issues that have directed developments in social and cultural pedagogy (both old and recent) such as issues of language, the emergence of a lifelong learning discourse, and the notions of community, solidarity and criticality.
\end{abstract}


Key-words: social and cultural pedagogy; historical transformations; adult education; youth education; social work.

\section{Las transiciones en el mundo de la vida: Mirando hacia atrás y hacia adelante después de cuarenta y cinco años de investigación en pedagogía social y la docencia en Lovaina}

Resumen: Este artículo presenta la reflexión del autor a partir de su experiencia de 45 años como investigador y docente en un programa de pedagogía social de la Universidad de Lovaina (Bélgica). Si bien el caso es interesante en sí mismo, es particularmente significante por su contribución a la comprensión de la evolución de la educación de adultos, la educación comunitaria y el trabajo social, tanto en términos disciplinarios como prácticos. Se presenta las fuentes de inspiración teórica desde diversas contextos lingüísticos, culturales, políticos y académicos. La cronología está organizada en cuatro períodos marcados por puntos de inflexión influenciados por acontecimientos internos y externos. La primera es la fase pionera. La segunda es fase de crisis y recuperación. La tercera es la fase de multiplicidad, y la última fase es la de reinvención. El documento también examina algunos de los principales temas y cuestiones que han dirigido la evolución de la pedagogía social y cultural (tanto antigua como reciente), tales como lenguaje, la aparición del discurso de la educación permanente, y las nociones de comunidad, solidaridad y criticidad.

Palabras-clave: pedagogía social y cultural; transformaciones históricas; educación de adultos; educación de la juventud; trabajo social.

\section{Transições do mundo da vida: Olhando para trás e para a frente depois de 45 anos de pesquisa em pedagogia social e ensino em Leuven}

Resumo: Este artigo apresenta reflexões do autor a partir de sua experiência de 45 anos como pesquisador e professor em um programa de pedagogia social na Universidade de Leuven (Bélgica). Enquanto o caso é interessante por si só, é particularmente significativa a sua contribuição para o entendimento da evolução da educação de adultos, a educação da comunidade e o trabalho social, tanto em termos disciplinares e práticos. Nós apresentamos as inspirações teóricas de diversos contextos linguísticos, culturais, políticos e acadêmicos. A cronologia está organizada em quatro períodos marcados por momentos de viragem em relação a eventos internos e externos. O primeiro é a fase pioneira. Em segundo lugar, a crise é a fase de recuperação. A terceira fase é da multiplicidade e a última fase é a reinvenção. Este trabalho também analisa alguns dos principais temas e questões que levaram a evolução (antiga e recente) da pedagogia social e cultural tais como a linguagem, a emergência do discurso da aprendizagem ao longo da vida, e as noções de comunidade, solidariedade e criticidade.

Palavras-chave: pedagogia social e cultural; transformações históricas; educação de adultos; educação de jovens; trabalho social. 


\section{Transitions in a life-world: Introduction}

Erinnerung in dem Sinne ist so etwas wie ein Antidepressivum, weil die Erinnerung dazu dient, das Blickfeld für Zukunftsperspektiven zu öffnen; Menschen, die keine Erinnerung haben, haben auch keine Zukunft: das heisst keine Entwurfskraft nach vorne $^{1}$. Oskar Negt, 2012, p. 61

I have been a witness of the development of the sub-discipline of social pedagogy in the Leuven University (Belgium) for about forty years, from the seventies till today, first as a student, then as an assistant professor and later as a professor. During that period I have been involved in a variety of research and teaching activities that have evolved over time. The unit of social pedagogy has been part of the faculty of psychology and educational sciences, in the publicly funded Catholic University of Leuven, which is a Dutch speaking university in the Flemish Community of Belgium. The university currently has some 40,000 students and covers all classical academic disciplines. It has existed for almost 600 hundred years, since 1425 .

The story of social pedagogy in Leuven is interesting in many respects. It reflects the changing context in which my colleagues and myself have been operating at local, national and international level. It represents the development of both teaching and research approaches throughout the years, including the continuities, tensions and disjunctions that inevitably direct the decisions over time. It shows the shifts in the sources that have inspired the protagonists for shorter and for longer periods. The history of social pedagogy in Leuven can be structured chronologically in four distinct phases. The pioneering phase, which lasted roughly from 1966 until the end of the seventies, was a time of experimenting with new forms of teaching and research. In the crisis and recovery phase, which covered mainly the decade of the eighties, we dealt with the insecurities of a society and a curriculum in crisis, but also nurtured the ambition to survive and renew. The multiplicity phase in the nineties and the first decade of this century represented a broadening of the scope, a growth of international connections, and an engagement with the policy discourse on lifelong learning. And finally, the re-invention phase that started at the end of the first decade of this century and gives direction to the current research activities in the 'Center for Education, Culture and Society', more particularly in the 'Laboratory for Education and Society' and to the curriculum of 'social and cultural pedagogy'. In addition to this chronological history, I will also present some of the main shifts, tensions and issues that have characterized social (and cultural) pedagogy in Leuven and abroad, such as the paradox of pedagogy and emancipation, the Anglo-Americanization of the research and teaching, and the sometimes diverging paths of a social work orientation, an adult education orientation and a human resources orientation.

The leitmotiv of my narrative will be 'the paradox of pedagogy' or, in a broader sense, 'the paradox of emancipation' that characterizes many educational practices and theoretical reflections. It refers to the dilemma of dependency and freedom, or the dilemma of disciplining and liberating. This paradox was affirmed by Kant, some two hundred years ago, as a key element of his pedagogical considerations. 'One of the greatest problems in education is how subjection to lawful constraint can be combined with the ability to make use of one's freedom. For constraint is

\footnotetext{
${ }^{1}$ Remembrance in this sense is somehow like an antidepressant, because remembrance helps to open future perspectives; people who have no remembrance neither have a future: that means, no forwardly directed design power (translation DW).
} 
necessary. How shall I cultivate freedom under conditions of compulsion?' (Kant, 1964, as cited in Lovlie, 2008). This paradox was echoed ever since in different domains and theories of education. Freire (1972) framed it as the opposition between banking education and problem-posing or liberating education, while choosing radically for the latter position. Chambers (1997) designed a radical reversal of expert and layperson positions as an answer to colonizing development practices. Others made the distinction between cultural deprivation theories, emphasizing the deficits of students, in contrast with cultural difference theories, paying attention to the capabilities of students (Banks, 1996). In recent years Rancière connected the paradox to the teacher-student relationship in his 'Ignorant Schoolmaster' (1991) and to the artist-spectator relationship in his 'Emancipated Spectator' (2009). In both contexts he criticizes processes of stultification of the participants by the 'master' and, in contrast, suggests to depart from the assumption of equality of intelligence, or from the competence of 'the incompetent' (2006, p. 83). Also in the field of practice the emancipation paradox has been continually experienced and discussed, particularly in the fields of popular education and social work, where the activities with/for marginalized people often surfaced this dilemma. It again recently came to the fore in the Netherlands in discussions about the (limited) relevance of professionalized social and cultural work in contrast with 'the power of civil society' (Spierts \& Duyvendak, 2013). Since this basic paradox inevitably also colored the history of social pedagogy, it will be an important thread in my reflections on the Leuven case in the following pages.

\section{Exploring new spaces: Experimentation and emancipation in the pioneering years}

In 1966 a new graduate program saw the light in the Faculty of Psychology and Educational Sciences in Leuven. After careful deliberations it was called social pedagogy. From the fifties and the sixties onwards, in the context of the development of the welfare state, increasing government subsidies were made available for voluntary practices in the third sector (NGO's, community organizations, youthwork, adult education, social work initiatives). Together with this government intervention came the requirement to professionalize these practices and to provide an academic foundation for the growing socio-cultural and social work sector in society. The new program was situated in the department of education. It focused on youth and adult education practices and theories, rather than on social work practices and theories, in contrast with Ghent university, where social work practice and theory was the main perspective (Coussée et al., 2010), and with Brussels University, that focused predominantly on cultural practices (Elias \& Van Wing, 2002). The Leuven program identified with the tradition of the 'freie Jugend und Erwachsenenbildung' as it had developed in Germany in the previous decades. This 'free' youth and adult education originally referred to non-formal practices taking place in the 'free time' (leisure time) of the participants involved. The adjective 'free' referred to the so-called 'third' educational environment of youth movements and provisions that had gained societal importance, next to the primary and secondary educational environments of the family and the school. In those days, there was also an explicit interest in 'arts education' (freie musische Bildung) in the context of exchange programs with a German arts education academy in Remscheid.

In the beginning years and also later on, many of the students that participated in this program had connections to this field of practice, as youthwork leaders. The beginning years were characterized by the optimism and voluntarism of the sixties and the attempts to modernize many of the institutions that played a role in the organization of culture, welfare provision, education and religion in our society. The growth of the provisions was also the result of the increasing importance 
of the welfare state, that had been established at the end of World War II and that saw its heydays in the seventies of the twentieth century.

From the very start, the program was quite popular and attracted a substantial number of students. The attractiveness was connected to the promise of an education that would not only reproduce tradition, but that would also, in an experimental way, contribute to the permanent renewal of modern society. By the seventies, the number of students graduating annually from this master's program increased to an average of 35. In that decade the students radicalized, as in many universities around the western world. This radicalization came to expression particularly with the start of 'project based education' in 1973, which articulated the renewal ambition that inspired not only social pedagogy, but of which social pedagogy was one of the forerunners at the Leuven university. The students, and to a less radical extent also the staff-members, that propagated this new approach were inspired by teaching experiments in many universities in the Netherlands, Germany and Scandinavia, thereby reconnecting to the older reform pedagogies in Europe (Pestalozzi, Montessori, Petersen) and progressive pedagogies in the U.S. (Dewey, Kilpatrick). The idea was to integrate different courses into projects of self-directed study-groups and to create connections with the field of practice, through activities that would support different organizations in the social and cultural field (Projektonderwijs, 1975).

The innovation was the result of intensive and sometimes conflicting collaborations and negotiations between students and staff in regular 'public meetings' where the orientations of the program were discussed and 'democratically' decided. The conflicts between staff and students were exemplary for the pedagogical paradox mentioned earlier: the dilemma of self-direction and external control. Students argued that, since they committed themselves intensively for their projects, they also had the right to determine freely what theories to integrate in their research, including the freedom to be the final evaluators of their work. The staff thought it its responsibility to give systematic lectures on social-pedagogical/andragogical theories and could not accept the students to be the ultimate judges of the quality of the projects. The negotiations about these issues lasted many years and eventually lost prominence when the student radicalism in general weakened. In spite of these tensions, graduates of the different generations made clear that they, almost unanimously, consider this part of the curriculum the most relevant experience in their student career and, later on, for their professional activities.

The theoretical orientations were rather eclectic, combining different elements from quite diverse sources of inspiration. The new staff-members looked in different directions, in the first place to the Netherlands (two part-time members came from there), but also to Germany, and to the Anglo-American world. In Germany 'social pedagogy' had existed since the end of the nineteenth century, in the context of a then changing, rapidly industrializing world, that seemed to disrupt the traditional social tissue. Charities, mostly run by upper-class women, policy-makers and representatives of the academic world, particularly of the then new social sciences, were concerned about the conditions in which youth and young adolescents were growing up (Michielse, 1977). The founding father of social pedagogy, the neo-Kantian philosopher Paul Natorp (1898), developed a theory that focused on the relationship between education and society, whereby 'the community' (in line with Tönnies' idea of 'Gemeinschaft') was constructed as the ideal-typical environment, creating opportunities for young people to achieve their 'true humanity' (das wahre Menschentum) (see also: Eriksson, 2010; Hämaläinen, 2012; Nuňez, 2007). As such, he reacted against individualizing psychological and educational approaches in the social sciences of that day. The German socialpedagogical tradition inspired later on, in the interbellum, Dutch authors such as Carl Mennicke (1937) who was mainly preoccupied with the education of youth and adolescents to become responsible citizens in society. At a later stage, Perquin (1966) referred to the 'pedagogical 
responsibility of society' and interpreted social pedagogy as an active intervention in the public domain. This emphasis on a community-oriented education, against the backdrop of a transforming society, has remained a central preoccupation of social pedagogical theory-building. In the sixties and seventies, the leading theoretician of social pedagogy in Germany was Klaus Mollenhauer (1964). For him, the central purpose of social pedagogy was to contribute to the emancipation of young people, through non-formal education that was experimental and open-ended. More recently, authors such as Böhnisch \& Münchmeier (1990) and Böhnisch (1999) have renewed the German tradition, while reflecting on the often the indistinct borders between practices of 'free' youthwork and of more re-educative social work. The German connection in the seventies also included the domain of adult education, through the collaboration of Walter Leirman, the Leuven Social Pedagogy professor of that day, with Franz Pöggeler at the Aachen university in Germany. This resulted in a book edited by Leirman (1979) on 'Erwachsenenbildung in fünf Kontinenten (Adult Education in Five Continents), and a honorary doctorate for professor Pöggeler in Leuven, in 1986.

Another important source of inspiration was the theory of andragogy in the Netherlands that emerged in the sixties. The founding father was Ten Have (1978) who defined andragogy as the combined practices of adult education, community work, social work and personnel work. He constructed an overarching andragogical theory that was strongly inspired by the American tradition of planned change that had its origins in the training laboratories of Kurt Lewin in M.I.T. Andragology obtained, in the seventies in the Netherlands, the status of a discipline next to pedagogy, sociology and psychology. Van Gent (1989) also situates the origins of the Dutch andragology in the German tradition of social pedagogy of the nineteen thirties. For about fifteen years (from 1970 to 1985) the discipline of andragology in the democratizing Dutch universities was very popular, attracting large numbers of students. In the seventies it also radicalized. Under the influence of the students and progressive staff members, 'critical andragogy' gained influence and numerous experiments both in teaching and research saw the light. Project based education proliferated and action research became the preferred methodology for the critical research practices. The critical perspective was definitely also inspired by Paulo Freire in Latin America who, in his 'Pedagogy of the Oppressed' (1972), developed new radical perspectives on adult literacy education. He obtained an honorary doctorate from the Leuven University in 1975. Also the German theorists of trade union education Oskar Negt and Alexander Kluge gained some influence with their work on exemplary learning (Negt \& Kluge, 1972). They also represented a link to the work of Habermas (1969) on the transformation of the public sphere and his later work on communicative action (1981).

As mentioned before, the Leuven unit of social pedagogy adopted the Dutch andragogical tradition as an important point of reference, next to the German emancipatory social-pedagogical tradition. These references also inspired the research projects that were carried out as action research projects during the seventies. One long-term project, called 'Project Education for Girls' studied and supported actions in Flemish society by a women's socio-cultural movement to stimulate young girls' participation in higher education.. A second series of projects under the heading of 'Youth and Emancipation' studied and supported innovative initiatives in 'free' youthwork initiatives in Flanders, in line with the German social-pedagogical tradition. A third major project focused on community work, considering the disadvantaged population in underprivileged urban neighborhoods as creative participants in urban renewal projects. There was an outspoken ambition to study and stimulate new themes and experiments of socio-cultural action, in free youthwork, in liberal adult education, and in community development. Contrary to what happened in the Netherlands, there was no intention to separate youthwork studies and adult education studies, and there was no focus yet on work-related education and learning. The direction was non-formal and leisure-time oriented. Social-pedagogy thrived on the general optimism that characterized those 
years, and the promise of attractive careers for academically trained socio-cultural workers in the subsidized sectors of the welfare state. There was optimism too about the emancipatory power of social-pedagogical interventions, in spite of the fact that many of the attempts to emancipate, already from the beginning days in the $19^{\text {th }}$ century, had difficulty to escape from paternalism, while reproducing continued dependencies rather than freedom and autonomy.

\section{The times they are a changing: from crisis to recovery}

At the end of the seventies and beginning of the eighties our societies struggled with an intensive economic crisis. The economy moved from quasi full-employment towards a situation of massive unemployment, especially among the younger population. The general insecurity of that day strongly influenced the political orientations. The relevance of the welfare state model, which had been successful during the first three postwar decades, was critically questioned. This hastened the adoption of more neo-liberal recipes for the organization of economic and public life. The crisis also became visible in the orientations of the students. The numbers of students that chose for education, and particularly for social pedagogy, decreased rapidly. Some of the remaining students also reflected a pessimistic, 'no future' mood and openly began to express doubts about the relevance of the emancipatory narrative of social pedagogy and andragogy, while pointing to their counter-productive effects. In the meantime, in the Netherlands, the success of the discipline of andragogy, that was one of the symbols of the redistributive welfare state, came to an end. The loss of prestige was further reinforced by a critical analysis, referring to the paradox of emancipation, about the role of welfare institutions and their workers, when trying to solve the problems of the disenfranchised sections of the population. Hans Achterhuis in his book 'De markt van welzijn en geluk' (1980) argued that the ones who profited most of the welfare provision were not the deprived people, but the 'andragogues' and their institutions who had managed to establish this 'market of wellbeing and happiness' in their own profit. In spite of the elaborate counter-arguments by defendants of andragogic interventions, the Achterhuis analysis definitely contributed to the weakening of the position of andragology as a separate discipline (Hake, 1992) and nurtured the neo-liberal critique on the welfare state.

These developments installed a sense of realism in the way the Leuven social pedagogy continued its journey. There were some doubts whether a separate graduate program could survive and contacts in view of a merger with school education, that began to show an increasing interest in adult training, were informally started. However, the distance between the two traditions seemed hard to bridge and social-pedagogy continued to run a separate program, certainly when the number of students again began to increase at the end of the eighties and the beginning of the nineties. Also in the research activities, a more pragmatic turn became manifest. There was a continuation of the community development focus, with a strong interest in the social learning aspects of urban renewal initiatives by local action groups. A certain skepticism about the possibilities of planned change was articulated in that context, since change often seemed to be the result of grassroots actions, and from unforeseen events, rather than from planned initiatives from above. More or less simultaneously, other collaborators at the center of social pedagogy invested much energy in the methodological development of community work. And also at that time, given the dramatic employment crisis in the country, the re-integration of the unemployed was addressed in various research projects. This was a precursor of the attention to be paid at a later stage to employability, activation and work-related learning.

The identity of the Leuven social pedagogy was further refined by the publication of two handbooks on 'Vormingswerk en vormingswetenschap' (the practice and theory of adult education), 
part 1 and part 2 (Leirman \& Vandemeulebroecke, 1981, 1984). ${ }^{2}$ The subtitles of both books are 'agologisch handboek, deel 1 en deel 2' (agological handbook, part 1 and part 2). Both publications were a genuine reflection of the pluralist perspectives and frames of reference of the Leuven team. They presented an eclectic mix of critical, scientific and practice oriented concepts, inspired by the inheritance of the German critical social pedagogy and, increasingly, by the Dutch/Anglo-American theories of planned change (Van Beugen, 1971; Lippitt et al., 1958). Alternative views in the Netherlands, as expressed by authors who questioned some of the myths of andragogical practice and theory such as Michielse (1977) and Nijk (1978), were not really dealt with in the Leuven school.

In the second half of the eighties, some of the initial optimism returned and announced the recovery of social-pedagogy in Leuven. This certainly had to do with the internationalization dynamics, prompted by the successful international conference 'Adult Education and the Challenges of the 1990s: Peace, Development, Employment, Environment and Technology' which resulted into the first important English publication of social pedagogy in Leuven (Leirman \& Kulich, 1987). The conference and the book showed the ambition to relate research and teaching in the Leuven socialpedagogy unit with the important issues of that time, but also to connect to researchers from different continents (Latin America, Canada, Europe, the US) and various European countries (France, Italy, the Netherlands, Germany, Belgium, Yugoslavia). In his opening address, Walter Leirman presented an ambitious program for adult education/social pedagogy aimed at dealing with the major societal issues of that time (poverty, environmental degradation, technological revolution, etc..), in a world that rapidly transformed into a 'global village'. The author also recollected the main sources of inspiration of the Leuven social pedagogy of the previous twenty years such as the Pedagogy of the Oppressed (Freire), the theory of communicative action (Habermas), the planning of change theory (Lippitt), the andragogical tradition (Ten Have, Van Beugen), the Anglo-American adult education (Knowles, Jarvis) and the German emancipatory social pedagogy (Giesecke, 1983; Mollenhauer, 1974). Postmodern critics would now call such a picture a grand narrative, paying little attention to the paradoxical effects of emancipatory practices. The critical comments on the negative impacts of andragogical actions in the Netherlands apparently had little influence on the way the future of social-pedagogy/andragogy in Leuven was imagined.

By the end of that decade, the graduate program had recovered from the crisis of the iron eighties' (Leirman). It again attracted enough students to remain independent. There also was an intensive increase of international collaboration through the establishment of an Erasmus Intensive Program on Adult Education, initiated by the Leuven Center of Social Pedagogy in 1989. The program had a fairly open, pluralist orientation with a central focus in 'liberal adult education', in spite of the fact that, at that time, policy orientations regarding adult education made a major shift, as Hake observed in a report on world trends. 'During the 1980s, it is clear that the priorities of public bodies have shifted significantly away from a relatively pluralistic approach to research on adult education towards an overwhelming concentration upon education and training in relation to employment (Hake, 1999, p. 130). This new trend was a foreboder of a development that would redirect the research and teaching of the Center of Social Pedagogy in Leuven at a later stage.

\section{Multiplicity: Convergence and divergence}

\footnotetext{
2 The notion of 'Vorming' is hard to translate into English. It is inspired by the notion of 'Bildung' in Germany which refers to the process of self-cultivation of the subject dealing with the task of finding a singular place in broader society. Vorming is not limited to the developmental stage of childhood and youth. It increasingly is understood as a process of lifelong education.
} 
The eighties indeed brought a remarkable shift in views on adult education. Several, sometimes contradictory, tendencies emerged, which were also reflected in the teaching and research in Leuven ${ }^{3}$. On the one hand there was the increased instrumentalization of adult education in view of overcoming the employment crisis. 'Employability' and 'work related education' became major topics in many adult education research centers in Europe, together with a reorientation from 'education' to '(lifelong) learning'. In line with this, also in Leuven, an increased interest in the policy discourse on lifelong learning could be noticed. This became manifest in applied research in the first half of the nineties focusing on the regional planning and coordination of lifelong learning initiatives (Gehre \& Desmet, 1998; Leirman, 1995). Simultaneously, there was a research on youth policy planning (Janssens et al., 2001). And, in those days, the issue of environmental awareness came to the fore in projects commissioned by authorities on the regional, national and European level (Janssens \& Wildemeersch, 2003; Jans \& Wildemeersch, 1998; Lombaert, 1995; Vandenabeele \& Wildemeersch, 2012). The interest in environmental issues also moved across borders in different interdisciplinary projects in Vietnam, in regions populated mainly by ethnic minorities, where the tension between economic and sustainable development was manifest (Bastrup-Birk \& Wildemeersch, 2011; Tessier et al., 2004; Wildemeersch, 2007).

In the 1990s and 2000s there were also initiatives to enrich the theoretical debate on adult education. The center played a central role in the three years reflection on 'New Challenges in Adult Education' in the Flemish socio-cultural field (Wildemeersch \& Goubin, 1992). A noteworthy contribution was Walter Leirman's (1994) book, at the end of his academic career, on the 'Four cultures of education: expert, engineer, prophet, communicator', to which he has recently added a fifth culture, the homo ludens. In this book he synthesized the different roles of educators in the field of adult education in general and in the social-pedagogical tradition (in Leuven) in particular. In the beginning of the nineties also the debate on postmodernity reached the Center of Social Pedagogy. In line with this, many of the ambitions of adult educators to contribute to radical social change were increasingly relativized. Some of the 'repressive myths' (Ellsworth, 1989) of (adult) critical pedagogy were articulated at various occasions. The debate between the (late-) modernists and post-modernists became quite intense and even violent, at the occasion of an international seminar organized in Leuven in 1990 on 'adult education, experiential learning and social change: the postmodern challenge' (Wildemeersch \& Jansen, 1991). The discussions in the wider field of adult education continued throughout the nineties and in the beginning of the new millennium. The Leuven center, together with Nijmegen University in the Netherlands, again brought various international researchers together in Leuven, to reflect on the question whether the enhancement of social responsibility was still a perspective for adult education in postmodern/late-modern times (Wildemeersch, Jansen, \& Finger, 1998). And, some ten years later, from 2007 till 2012, an intensive international collaboration started with social geographers on the question of how to deal with plurality and diversity in urban contexts (see: van der Veen \& Wildemeersch, 2012). This international study program resulted recently in a new research project, bringing together seven research centers and numerous NGO's in the Flemish Community, to investigate the state of solidarity in present-day circumstances and to experiment with new forms of solidarity. More recently, the interest in the relationship between social pedagogy, citizenship and democracy gave rise to an intensive collaboration with Ghent University at the occasion of the installation of the International Francqui Chair in Ghent, awarded to professor Gert Biesta, related to 'Learning in Public Places' (Biesta, 2011; Biesta, De Bie, \& Wildemeersch, 2013).

\footnotetext{
${ }^{3}$ In the beginning of the 1990's the name of the centre was formally converted into 'social and family pedagogy'.
} 
The concern with unemployment and employability had gradually broadened toward a more general interest in work-related forms of continuing education, initially in the non-profit sector, but from 2000 onwards also in the profit sector (Baert \& De Rick, 2005). This development coincided with the trend, as described above, whereby adult and continuing education were increasingly integrated, in the policy narrative of lifelong learning (Baert et al., 2001). This line of research was stimulated by diverse external bodies, such as the European Commission and particularly the OECD. Amongst others, this resulted into an E.U.-project where we explored, via case study research in six European countries, experiments trying to create opportunities for the young unemployed to participate in work life (Weil et al., 2005; Wildemeersch \& Weil, 2008). Parallel to this, the research on community work in disadvantaged communities, which had a long tradition in social pedagogy, was continued also in the previous two decades (Baert et al., 1999; Baert \& Droogmans, 2010). This concern was also connected with the research line on 'citizenship' that started with the ETGACE project (Education and Training for Governance and Active Citizenship in Europe), resulting into various conferences and publications (Stroobants et al., 2002; Wildemeersch et al., 2005). Also our concern about the tensions of the multicultural society, including its consequences for education, became an important point of interest in our research and teaching ${ }^{4}$ (Wildemeersch \& Van Heeswijck, 2007). Later on, the reflection on all these issues brought us also to Teachers College at Columbia University in New York, where we co-organized a three days seminar on 'Democratic Practices as Learning Opportunities' (van der Veen et al., 2007).

With regard to the teaching activities, there was both continuity and renewal. The continuity definitely was related to the inheritance of project-based education. In recent years this teaching approach remained the core of the Leuven graduate program of social pedagogy, and to a certain extent also a model for other teaching activities elsewhere (Baert et al, 2002). In line with this, there was also an intense collaboration for a few years with two South-African universities (Kwazulu Natal and Cape Town), to explore the relevance of project-based learning (Pbl) for university adult education reforms in post-apartheid South Africa. It was concluded that $\mathrm{Pbl}$ 'has the potential of allowing students to construct new knowledge which is action-oriented and socially relevant; of emphasizing collective learning and promoting an inclusive approach to knowledge production and dissemination; and of strengthening critical reflectivity and creativity' (von Kotze \& Cooper, 2000, p. 212). However, concerns were raised about universities becoming more vocationally and market oriented, and $\mathrm{Pbl}$ being used to support the ideology of 'new vocationalism' rather than a more radical and critical education agenda. As mentioned before, the trend towards new vocationalism became omnipresent in adult education research and teaching at universities. Also at Leuven University, since the eighties, it had been thought important to pay attention to work-related teaching and research. In line with this, in 2006, the name of the center and the program was changed into 'sociale en arbeidspedagogiek' (social and work pedagogy). The idea was that the social pedagogy line and the work pedagogy line should not be developed separately, but could inspire each other, with the continuation of the critical perspective that had characterized social pedagogy since its beginning years. However, the reality was that both orientations increasingly drifted apart, which resulted into the decision in 2010 to formally split up the center into two autonomous entities, on the one hand POOLL (Centrum voor Professionele Opleiding en Ontwikkeling en Levenslang Leren - Center for Professional Training and Development and Lifelong Learning), and on the other hand the Laboratory for Education and Society (LES), integrated in the Center for Education, Culture and Society (ECS). ECS created a new graduate program of social and cultural pedagogy, with the intention to connect social and cultural perspectives to a variety of formal and

${ }^{4}$ For a short period (2002-2006) a research group on 'Intercultural, Development and Comparative Pedagogy' was operational 
non-formal practices of education and to renew the critical perspective on education. This whole reshuffling of research centers took place against the backdrop of a quasi-silent operation at the faculty level, where the two separate departments of psychology and of educational sciences merged into one whole.

\section{Reinventing social and cultural education as public pedagogy}

In 2010 the inheritance of social pedagogy was thus continued and renewed both in research and teaching. The major research tradition of social pedagogy found a new home in the Laboratory of Education and Society that brought together researchers from philosophy of education and those researchers from social pedagogy that had their main interest in socio-cultural issues. This 'laboratory' was embedded in the larger structure of the Education, Culture and Society Center (ECS), which created a new dynamics in research approaches and practices. As its general mission, ECS aims at the study of education in the intersection between the individual and society, thereby developing the exploration of a broad range of educational processes (e.g., parenting, schooling, guidance, social and cultural practices) with a particular focus on the interplay between education and changing structures of society and culture (Faculty of Psychology and Educational Sciences, 2011, p. 62-64). In line with this, ECS-research intends to deal with issues such as the digitalization of society and its consequences for education, the ongoing pluralization of society (including issues related to (forced) migration and globalization), and the influence of professionalization on educational practices.

In order to develop an educational theory that offers an adequate response to these three issues, ECS aims at the elaboration of an experimental, multi-disciplinary approach at the crossroads of empirical and theoretical-philosophical research. In line with the insights of the new pragmatism (Latour, 2005), this experimental approach also intends to leave behind the often 'anti-technological' stance of much educational philosophy theory (see also: Fenwick \& Edwards, 2013). The experimental approach will also be reflected in the teaching programs at undergraduate and graduate levels. ECS aims at designing these programs so that they are in themselves both a way to do research and an object of research. In these educational programs particular attention is paid to the experimental design of 'educational practices', i.e. the development of implementable practices and technologies that are a response to a concrete question (a pressing issue that is related to one or more of the three above-mentioned issues).

In this way, the teaching program of 'social and cultural pedagogy', at the level of the undergraduate and graduate courses, is very much connected to the research program. Particularly at the graduate level, students are invited act as 'researchers' rather than 'learners'. In that sense the position of the staff is basically not different from that of the student. They both are researchers trying to understand better the reality in general and the relationship between individual and society with regard to educational practices and policies. This resembles very much the radical ambitions of the protagonists of project-based education forty years ago. Therefore, project based education is still at the heart of the curriculum of the new graduate program of social and cultural pedagogy, in combination with another core subject which is called 'laboratory of social and cultural pedagogy', inspired by Masschelein's experiments with students exploring foreign cities by walking, in different continents (Masschelein, 2010). In both 'courses' in particular, but in the entire program in general, students are invited, in close collaboration with the field of practice and with the staff members, to investigate issues at stake in various domains of formal and non-formal education, and to develop a response to that issue; in other words: to clarify how they position themselves theoretically and practically with regard to that issue, and how they would design a possible alternative. In that sense, the study practice is again very experimental, as in the beginning years, whereby the students are 
invited to engage openly with the issue at stake, without many preconceived notions on how 'the problem could be solved' and, without positioning themselves as experts who, after 'diagnosis of the problem' will arrive at an adequate answer, solution, advice, etc. This emphasis on an open and experimental attitude is definitely also influenced by a raising interest in aesthetics and arts practices in the curriculum. An important difference however with the seventies is that we now live in a different world, with less optimism and more uncertainties than forty years ago, and that initiatives to innovate the program now come from the staff rather than from the students.

Yet, the very fact that there is a lack of secure perspectives may create new opportunities to open spaces of experimentation, where a plurality of perspectives can be confronted and explored. Such limit situations have the potentiality to become moments of democratic, public education, where traditional hierarchies are challenged and issues are made public. And it is exactly this kind of issues that may create opportunities for 'public' education (Sandlin et al., 2010). Its hope is to 'make things public', to play a role in the creation of matters of public concern (Simons et al., 2009). In this approach to public pedagogy, the point of departure is not the 'knowing' of the expert, but rather the commitment to create a public space where both the teacher and the learner in their own way, and departing from their particular capabilities, engage in a in process of co-investigation and joint experimentation without having a clear answer on beforehand of what the outcome of the process will be. This 'pedagogy of the unknowable' (Ellsworth, 1989, 2005) or 'pedagogy of the unknown' (Sandlin, 2010) is also a critical pedagogy. However, it is not only critical about the societal conditions, but also about the capacity of the educator to show the way. In Rancière's terms, this educator resembles the 'ignorant schoolmaster'. In this concrete situation of insecurity, this schoolmaster 'does not teach his pupils his knowledge, but orders them to venture into the forest of things and signs to say what they have seen and what they think of what they have seen, to verify it and have it verified' (Rancière, 2009). In line with this approach, one could speak in a somewhat provocative way of an 'ignorant' pedagogy rather than a pedagogy of the unknowing. In this 'ignorant' pedagogy, the emancipated participant is the point of departure rather than the end-point of the process. And the educational process is not framed in terms of 'where to', but in terms of 'where from'.

\section{Looking backward and forward: some important themes and issues}

I have analyzed the evolution of social (and cultural) pedagogy in my university over a period of almost half a century. I am sure that such an analysis is not only interesting for 'the locals', but has relevance for researchers, workers and volunteers in varied places and spaces, particularly since the concept of 'social pedagogy' seems to generate new international interest. The specific case described in this paper represents general tendencies that became manifest in many parts of the western world in line with rapid globalization and neo-liberalization processes that implied a radical attack against the provisions of the welfare state (Judt, 2010). An important illustration of this influence is how over the last twenty years the language researchers in social pedagogy use to express their findings and insights, increasingly has become English, at the detriment of local languages, in our case the Dutch language. Local academic journals have rapidly disappeared. Researchers write mainly English books and articles now, with some important exceptions. The evolution of social pedagogy in Leuven also shows how this development has brought an impoverishment, since the rich tradition of German and other continental European forms of reflection on practices of youth and adult education and social work has been moved to the margins. In line with this, Biesta (2012) makes a point when he observes that in the recent North-American Handbook of Public Pedagogy (Sandlin et al., 2010) 'there is little acknowledgement of the rich history of educational work in adult, community and popular education, and of the Continental tradition of what, with a rather limited 
translation of the German word "Sozialpädagogik", might be referred to as "social pedagogy" (Biesta, 2012, p. 691). In spite of the fact that the move towards Anglo-American literature has often opened interesting horizons, the linkages with the local discourses and with the continental traditions should again be reinforced. Therefore, a revitalization and renewed recognition of publications in the different languages of the Continent seems important and urgent, without necessarily giving up the connection with English as the lingua franca of the international academic world.

This is illustrated by the recent publication in our research center of the book 'Apologie van de school (In Defense of the School)' by Masschelein and Simons $(2012,2013)$ that has generated a lot of local interest and debate, since the book was published in Dutch and hence, accessible to a wider public. In their plea for the school as a democratic public place they particularly draw on continental authors, with Rancière as one of the main sources of inspiration. They present the school in the first place as a democratic space where students are invited to move beyond the selfevidence of their own destiny. This resembles very much the position of the Barcelona based socialpedagogue Violeta Nuňez, who suggests to consider education as a space against the social fixation of destinies. 'Partimos de considerar a la educación como un anti-destino, pues se trata de una práctica que posibilita la redistribución social de las herencias culturales’ (Nuňez, 2007, p. 4). Social pedagogy, in her view is 'a praxis', and therefore has to create this free space to go against the grain, be it in non-formal as well as in formal contexts. In this way, the social-pedagogical positioning that originally was connected to spaces of non-formal education ('free' youth and adult education and social work practices) is replaced by a positioning that links freedom to social and cultural actions in various contexts, rather than restricting it to non-formal contexts. This is also the way the present Leuven vision on social and cultural pedagogy is presented in its mission statement (see above).

Another important theme which has given direction to the research and teaching in Leuven and elsewhere is that of community and community building. As mentioned above, 'the idea' of a community has inspired social pedagogical theories and practices since its beginning days. However, in the meantime we have learned from history to what extent idealizing the community can lead to ethnocentric and xenophobic reactions, excluding those who are considered strange or non-familiar. Nevertheless, the reference to community in social and pedagogical practices and theories remains very important, particularly in societies that tend to overemphasize the role and responsibility of individuals, thereby neglecting the importance of connections, bonds and relationships among people, for the wellbeing of individuals and society as a whole. An inspiring view on community has been introduced some years ago by Lingis (1994) in 'The Community of Those who Have Nothing in Common'. Such community does not eliminate difference; on the contrary, it takes difference as an important constituent of what present day communities in a pluralist world could be about. Such communities could be conceived of as social laboratories. They are not communities that already dispose of a closely knit network of mutual relations. They are not based on a shared set of values, but are based on what Rorty (1999) describes as 'an ethics without principles'. And, both Lingis and Rorty argue that, in order to feel responsibility for a community or a person, we don't need shared values and norms, but most importantly a sense of solidarity.

This notion of solidarity (the third dimension of modern ideas of democracy, next to freedom and equality) seems to be a bit neglected in present day theories of democratic education. This may be the result of the Anglo-American turn described above, where indeed, with regard to democratic practices, a strong emphasis is put on freedom in the first place. In many pedagogical reflections on democratic educational practices a central notion currently used is that of 'interruption' (Biesta, 2006) or 'suspension' (Masschelein, 2006). Both authors point to the importance of subjects to be challenged in their certainties and self-evident life-world, thereby 
arguing against the dominant discourse of self-directed learning which is so dominant in AngloAmerican theories of adult education. In their view, the educational experience is basically characterized by moments of insecurity, questioning, and de-familiarization. In line with this, the process of education is associated with moments of interruption, by others or by external events, whereby taken-for-granted answers may be suspended. Such moments of questioning could be called 'pedagogical moments' or 'democratic moments', leading the subjects away from the certainties of the self-evident routines and convictions, and bringing about change in the existing hierarchies among people, things and power-relationships.

Finally, it is important also to reflect further on the 'critical' dimension of social and cultural pedagogy. For many years, we were in quite comfortable positions regarding this issue and we quickly had our answers ready when invited to clarify what we meant by criticality, critical reflection, critical education, etc. Many authors put such notions central in their reflections on education (Brookfield, 2009) and of course these are also central principles in the work of Paulo Freire (Freire, 1973; Schugurensky, 2011). Intriguing however, is that today these principles - which originally had a subversive and 'interruptive' character, are today expressed in various mainstream policy documents on education, or in all kinds of mission statements, at different levels and in various contexts of education and training. Such inflation inevitably devaluates the meaning of critical reflection and should invite us to remain skeptical about the way the notion operates in present-day discourses on education, social pedagogy and social work. As mentioned before, critical reflection is one of the major principles of education inspired by the enlightenment. However, earlier in this paper, I referred to the growing skepticism about the grand narratives of the enlightenment and about the paradoxes of emancipation that held adult education/social pedagogy captive. Therefore it is important to reflect anew about what critical social and cultural pedagogy can mean today. Philosophers such as Foucault have taught us that the capacity to be critically reflective in the current context of 'governmentality' often means that individuals are expected to be self-reflective. This self-reflection is now an important aspect of new technologies of power that have currently developed from hetero-control to auto-control, and in which strategies of lifelong learning play an important role (Fejes \& Dahlgren, 2012; Popkewitz, 2011; Rose, 2008). Also Rancière has thought us, as we have seen above, to be skeptical about strategies of 'empowerment' so popular nowadays in diverse contexts of education. He has shown how these strategies, in a paradoxical way, often imply a stultification of so-called non-experts by experts. In line with these observations, a new conception of 'critique' is being explored in educational theory and practice, also in the Leuven context. A point of departure here is that, contrary to the suggestion that experts, activists, 'public intellectuals' or vanguards can show the way towards better conditions, there is the experience that for many challenges we face today, there are no clear answers or directions on how to develop solutions. Many important challenges remain unaddressed or unresolved because the technical, political, educational answers remain inadequate. And such challenges in some cases create moments of crisis, of uncertainty, of interruption or suspension. And exactly these moments could be 'pedagogical' and 'democratic' moments. They could be the point of departure of processes of investigation and experimentation that bring new, unexpected answers to old questions, such as the ones that have been asked ever since social pedagogy took shape in the nineteenth century, when the 'social question' was being addressed by volunteering, often female, practitioners, innovative policy makers exploring the contours of the welfare state under construction, and critical social and educational scientists inventing new understandings of the relationship between individual and society, while freeing themselves from moral orientations that had for centuries directed the lives of people. But as we know, liberation inevitably creates new dependencies that in their turn have to be questioned again. So, the critical role of social and cultural pedagogy seems to be a story that has no end, at least for the time being. 


\section{References}

Achterhuis, H. (1980). De markt van welijg en geluk. Baarn: Ambo.

Baert, H., De Bie, M., Desmet, A., Hellinckx, L., \& Verbeke, L. (Eds.) (1999). Handboek samenlevingsopbouw in Vlaanderen. Brugge: Die Keure.

Baert, H., Kusters, W., Scheeren, J., \& Van Damme, D. (2001). Aanknopingspunten voor een positiebepaling van het Sociaal Cultureel Werk inzake levenslang leren. Vorming: Vaktijdschrift voor Volwasseneneducatie en Sociaal-cultureel Werk, 16(5), 335-350.

Baert, H., Beunens, L., \& Dekeyser, L. (2002). Projectonderwijs: sturen en begeleiden van leren en werken. Acco, Leuven, Leuven, 2002.

Baert, H. \& De Rick, K. (2005). Apprenticeship as a learning event. LLinE: Lifelong learning in Europe, 10, 94-101.

Baert, H., \& Droogmans, A. (2010). Bind-Kracht door basisschakelmethodiek. Een opstap in armoedebestrijding. Tielt: Lannoo Campus.

Banks, J.A., (1996). Multicultural education, transformation knowledge, and action: historical and contemporary perspectives. New York: Teachers College Press.

Bastrup-Birk, H. \& Wildemeersch, D. (2011). Navigating the tides of change: Revisiting the notion of reflexivity in the context of social learning for transboundary collective experimentation. Studies in Continuing Education, 33(3), 219-234.

Biesta, G. (2006). Beyond learning. Democratic education for a buman future. Boulder, CO: Paradigm Publishers.

Biesta, G. (2012). Becoming public: public pedagogy, citizenship and the public sphere. Social and Cultural Geography, 13(7), 683-697.

Biesta, G. (2011). Learning in public places. Civic learning for the $21^{\text {st }}$ century. Inaugural Lecture at the Ghent University at the occasion of the award of the International Francqui Professorship to dr. Gert Biesta.

Biesta, G., De Bie, M. \& Wildemeersch, D. (2013). Learning in public places. Civic learning, democracy and the public sphere. Dordrecht - New-York: Springer Academic + Business reports (in press).

Böhnisch, L. \& Münchmeier, R. (1990). Pädagogik des jugendraums. München: Juventa.

Böhnisch, L. (1999). Sozialpädagogik der lebensalter: Eine einführung. Weinheim: Juventa.

Brookfield, S. (2009). Critical reflection. Promises and contradictions. European Journal of Social Work, 12(3), 293-304.

Chambers, R. (1997). Whose reality counts? Putting the last first. London: Intermediate Technology Publications.

Coussée, F., Bradt, L., Roose, R. \& Bouverne-Debie, M. (2010). The emerging social-pedagogical paradigm in UK child and youth care: Deus ex machina, or walking the beaten path. In: British Journal of Social Work, 40, 789-805.

Elias, W. \& Van Wing, T. (Eds.). (2002). Vizier op agogiek. Leuven: Garant.

Ellsworth, E. (1989). Why doesn't this feel empowering? Working through the repressive myths of critical pedagogy. Harvard Educational Review, 53(3), 243-272.

Ellsworth, E. (2005). Places of Learning. Media, Architecture and Pedagogy. New-York: Routledge

Eriksson, L. (2011). Community development and social pedagogy: Traditions for understanding mobilization for self-development. International Journal of Community Development, 46(3), 403420.

Faculty of Psychology and Educational Sciences. (2011). Self-assessment report. KU Leuven.

Faure, E. (1972). Learning to be. Paris: UNESCO. 
Fejes, A. \& Dahlgren, M. (2012). The confessing society. Foucault, confession and practices of lifelong learning. New-York - London: Routledge

Fenwick, T. \& Edwards, R. (2013). Performative ontologies: socio-material approaches to researching adult education and lifelong learning. European Journal of Research on the Education and Learning of Adults, 4(1), 49-63.

Freire, P. (1973). Pedagogy of the oppressed. Harmondsworth: Penguin.

Gehre, G. \& De Smet, P. (1995). Een instrumentarium voor EduFora: een kennismaking, model van streekcharter, regiokaart, behoeftedekkingsrapport, educatief richtplan. KU Leuven: Centrum Sociale Pedagogiek.

Giesecke, H. (1983). Die jugendarbeit. München: Juventa.

Habermas, J. (1969). Strukturwandel der offentlichkeit: Untersuchungen zu einer kategorie der bürgerlichen gesellschaft. Neuwied: Luchterhand.

Habermas, J. (1981). Theorie des kommunikativen Handelns (Band 1 \& 2). Frankfurt a/M: Suhrkamp.

Hake, B.J. (1992). Remaking the study of adult education: The relevance of recent developments in the Netherlands to the search for disciplinary identity. Adult Education Quarterly, 42(Winter), 63-78.

Hake, B.J. (1999). Adult education research trends in the Western European countries. In W. Mauch (Ed.), World Trends in Adult Education Research. Hamburg: UNESCO Institute for Education.

Hämälainen (2012). Social pedagogical eyes in the midst of diverse understandings, conceptualizations and activities. International Journal of Social Pedagogy, 1(1), 3-16.

Jans, M. \& Wildemeersch, D. (1998). Natuur-en milieueducatie: van overtuigen naar overleggen. Brussel: Koning Boudewijnstichting.

Jansen, T. \& Wildemeersch, D. (1996). Adult education and critical identity development. From a deficiency towards a competency approach. International Journal of Lifelong Education 15(5), 325340.

Janssens, C., Van Duffel, K. \& Wildemeersch, D. (2001). Policy planning as social learning. In Schemmann, M. \& Bron, M. (Eds.), Adult Education and Democratic Citizenship IV. Krakow: Impuls Publisher.

Janssens, C. \& Wildemeersch, D. (2003). Social learning in interactive policy processes. The case of city forest planning in Flanders. In D. Wildemeersch \& V. Stroobants (Eds.), Connections. Active Citizenship and Multiple Identities. KU Leuven, Centrum Comparatieve, Interculturele en Ontwikkelingspedagogiek (conference proceedings - 4-6 September) (pp.141-156).

Judt, T. (2010). Ill fares the land. New-York - London: Penguin.

Latour, B. (2005). Reassembling the social. An introduction to actor network theory. Oxford: Oxford University Press.

Leirman, W. (1979). Erwachsenbildung in fünf kontinenten. Bestandsaufnabme und vergleich. Stuttgart: Kohlhammer.

Leirman, W. \& Vandemeulebroecke, L. (Eds.). (1981). Vormingswerk en vormingswetenschap. Een agologisch handboek. Deel 1. Leuven: Helicon

Leirman, W. \& Vandemeulebroecke, L. (Eds.). (1984). Vormingswerk en vormingswetenschap. Een agologisch handboek. Deel 2. Leuven: Helicon

Leirman, W. \& Kulich, J. (Eds.). (1987). Adult education and the challenges of the 1990s. Beckenham: Croom Helm.

Leirman, W. (1994). Four cultures of education: Expert, engineer, prophet, communicator. Peter Lang: Frankfurt.

Leirman, W. (1995). The future of adult education and lifelong learning in Europe. Report of the final colloquy. KU Leuven: Afdeling Sociale en Gezinspedagogiek. 
Lingis, A. (1994). The community of those who have nothing in common. Bloomington, IN: Indiana University Press.

Lippitt, R., Watson, J. \& Westley, B. (1958). The dynamics of social change. New York, NY: Brace \& Jovanovich.

Lombaert, G., Wildemeersch, D., D'Andrea, L. \& Declich, G. (1995). Between expansion and restriction. The development and facilitation of ecological responsibility in Flanders and Southern Italy. Report presented to the Commission of the European Union. Leuven: K.U. Leuven, Roma: Cerfe.

Lovlie, L. (2008). The pedagogical paradox and its relevance for education. Paper presented at the Institute for Educational Research, University of Oslo. Retrieved (4/4/2013), from www.philosophyof-education.org/conferences/pdfs/Lars.pdf

Masschelein, J. (2006). Experience and the limits of governmentalilty. In: Educational Philosophy and Theory, 38, 561-576.

Masschelein, J. (2010). The idea of critical educational research: Educating the gaze and inviting to go walking. In I. GUR ZE-EV (Eds.), The Possibility/Impossibility of a New Critical Language in Education. Rotterdam: Sense (pp. 275-291).

Masschelein, J. \& Simons, M. (2013). In defence of the school. A public issue. Leuven: E-ducation, Culture and Society Publishers (https://ppw.kuleuven.be/english/ecs/les/in-defence-of-theschool/jan-masschelein-maarten-simons-in-defence-of-the.html)

Masschelein, J. \& Simons, M. (2012). Apologie van de school. Een publieke zaak. Leuven: Acco.

Mennicke, C.A. (1937). Sociale Paedagogie. Grondslagen, vormen en middelen der gemeenschapsopvoeding. Utrecht: Bijleveld.

Michielse, H. (1977). De burger als andragoog: een geschiedenis van 125 jaar welzijnswerk. Meppel/Amsterdam: Boom.

Mollenhauer, K. (1974). Einführung in die sozialpädagogik. Weinheim: Beltz (4th edition).

Natorp, P. (1898). Sozialpädagogik. Theorie der willenserzięung auf derg grundlage der gemeinschaft. Stuttgart: Frommann (3. Auflage)

Negt, O. (2012). Dankrede: Maulwurf und schnecke. In Bissinger, M. Hg (Ed.). Demokratie Lernen. Zur Verleibung des Oskar-Bebel-Preises an Oskar Negt. Göttingen: Steidl

Negt, O. \& Kluge, A. (1972). Öffentlichkeit und erfahrung. Zur organisationsanalyse bürgerlicher und proletarischer offentlichkeit. Frankfurt a.M.: Suhrkamp.

Nijk, A. (1978). De mythe van de zelfontplooiing en andere wijsgerig-andragologische opstellen. Meppel/Amsterdam: Boom

Nuňez, V. (2007). PedagogÍa social: una lugar para la educación frente a la asignación social de los destinos. URL: http://www.porlainclusion.educ.ar/documentos/Violeta_N_Pedagogia_Social.pdf (retrieved the 23rd of December 2012)

Perquin, N. (1966). De pedagogische verantwoordelijkheid van de samenleving. Romen: Roermond.

Popkewitz, T. (2011). Pisa. Numbers, Standardizing Conduct, and the Alchemy of Standardizing Subjects. In M.E.Pereyra, H.G. Kothoff \& B. Cowen (Eds.). PIS A under examination: changing knowledge, changing texts and changing schools. Rotterdam: Sense (pp. 31-46).

Projektonderwijs in de studierichting sociale pedagogiek: een blauwdruk (1975). Afdeling Sociale Pedagogiek, Faculteit der Psychologie en Pedagogische Wetenschappen. Leuven: KU Leuven.

Rancière, J. (1991). The ignorant schoolmaster. Five lectures in intellectual emancipation. Stanford: Stanford University Press.

Rancière, J. (2006). The hatred of democracy. London - New-York: Verso.

Rancière, J. (2009) The emancipated spectator. London: Verso.

Rorty, R. (1999). Ethics without principles. In R. Rorty (Ed.), Philosophy and Social Hope. New-York London: Penguin. 
Rose, N. (2008). Powers of freedom. Reframing political thought. Cambridge: Cambridge University Press. Sandlin, J. (2010) Learning to Survive the "Schopocalypse": Reverend Billy's anti-consumerist "Pedagogy of the unknown." Critical Studies in Education, 51(3), 295-311.

Sandlin, J., Schulz, B., \& Burdick, J. (Eds.). (2010). Handbook of public pedagogy. Education and learning beyond schooling. New-York: Routledge.

Schugurensky, D. (2011). Paulo Freire. London-New-York: Continuum International Publishing Group.

Simons, M., Olssen, M. \& Peters, M. (2009). Handbook on matters of public concern. Introduction and overview. In M. Simons, M. Olssen \& M. Peters (Eds.), Re-Reading education policies. A bandbook studying the policy agenda of the $21^{\text {st }}$ century, Rotterdam: Senge (VII-XVI).

Spierts, M. \& Duyvendak, J.W. (2013). Stille krachten van de verzorgingsstaat verdienen beter. Tijdschrift voor Sociale V raagstukeken, voorjaar, 2013(1), 20-24.

Stroobants, V., Wildemeersch, D., Snick, A. \& Celis, R. (2002). Challenge, capacity and connection. In J. Holford, J. Preece \& M. Soler Gallart (Eds.), Learning Active Citizenship and Governance in Late Modern Society. A European Perspective. University of Surrey: Department of Educational Studies, 84-98.

Ten Have, T.T. (1978). Andragogie, een terreinverkenning. Groningen: Wolters-Noordhoff.

Van Beugen, M. (1971). Sociale technologie en het instrumentele aspect van de agogische actie. Assen: Van Gorcum.

Vandenabeele, J. \& Wildemeersch, D. (2012). How farmers learn about environmental issues. Reflections on a socio-biographical approach. Adult Education Quarterly, 62(1), 56-72.

Van der Veen, R., Wildemeersch, D., Marsick, V. \& Youngblood, J. (Eds.). (2007). Democratic practices as learning opportunities. Rotterdam: Sense.

Van der Veen, R. \& Wildemeersch, D. (Eds.). (2012). Special issue: Learning to live together in diverse cities: Educational and socio-geographical perspectives. International Journal of Lifelong Education. 31(1), 1-110.

Van Gent, B. (1989). Andragogy and andragology in the Netherlands: Issues in the definition of a scientific discipline. In B.J. Hake \& W.J. Morgan, Adult Education, Public Information and Ideology (pp. 19-26). Nottingham: Department of Adult Education.

von Kotze, A. \& Cooper, L. (2000). Exploring the transformative power of project-based learning in the context of university adult education. In Studies in the Education of Adults, 32(2), 212-228.

von Werder, L. (1980). Alltägliche erwachsenenbildung. Aspekte einer bürgernahen pädagogik. Weinheim: Belz.

Weil, S., Wildemeersch, D. \& Jansen, T. (2005). Unemployed youth and social exclusion in Europe. Learning for inclusion? Aldershot: Ashgate.

Wildemeersch, D. (2007). Social learning revisited. Lessons learned from North and South. In: A. Wals \& T. Leij, van der, (Eds). Social learning towards a more sustainable world (pp. 99-116). Wageningen: Wageningen University Press.

Wildemeersch, D. \& Jansen, T. (1991). Adult education, experiential learning and social change: The postmodern challenge. The Hage: Vuga.

Wildemeersch, D. \& Goubin, J. (Eds.) (1992). Het vormingswerk uitgedaagd. Mechelen: Vlaams Centrum voor Volksontwikkeling.

Wildemeersch, D., Jansen, T. \& Finger, M. (Eds.) (1998). Adult education and social responsibility. Reconciling the irreconcilable? Frankfurt: Peter Lang.

Wildemeersch, D. \& Vanheeswijck, H. (2007). Reconsidering dialogue in intercultural learning and education. In Pollefeyt, D. (Ed.), Interreligious Learning, Leuven: Peeters (pp. 255-273).

Wildemeersch, D. \& Weil, S. (2009). Social sustainability and activation strategies with unemployed young adults. In Willis, P. (Ed.), Retbinking work and learning. Berlin: Springer. 


\begin{abstract}
About the Author
Danny Wildemeersch

Leuven University

Email: danny.wildemeersch@ppw.kuleuven.be

Danny Wildemeersch is now a Professor Emeritus of Social and Intercultural Pedagogy at the University of Leuven in Belgium. From 1994 till 2002 he also was a full professor of Social Pedagogy and Andragogy at the University of Nijmegen in the Netherlands. He is a member of the Laboratory for Education and Society. He teaches courses in adult education and global and intercultural education. His research focuses on intercultural education, learning and social participation, intercultural dialogue, citizenship education, adult education, environmental learning, transitions from school to work, and participation in development cooperation. He is co-editor of the European Journal for the Research on the Education and Learning of Adults (RELA).
\end{abstract}

\title{
About the Guest Co-Editors
}

Daniel Schugurensky

Arizona State University

Email: dschugur@asu.edu

Daniel Schugurensky is Full professor at Arizona State University, where he has joint appointment in the School of Public Affairs and the School of Social Transformation. He is the Head of the Area of Justice and Social Inquiry, and the coordinator of the Masters program in social and cultural pedagogy. He has written extensively on youth and adult education, community development and participatory democracy. Among his recent authored and co-edited books are Ruptures, continuities and re-learning: The political participation of Latin Americans in Canada (Transformative Learning Centre, University of Toronto, 2006), Four in Ten: Spanish-Speaking Youth and Early School Leaving in Toronto (LARED, 2009), Learning citizenship by practicing democracy: international initiatives and perspectives (Cambridge Scholarly Press, 2010), Paulo Freire (Continuum, 2011), and Volunteer work, informal learning and social action (Sense 2013).

Michael Silver

Arizona State University

Email: Michael.Silver@asu.edu

Michael Silver is a Research Fellow at the National Center on Education and the Economy and the Center for the Future of Arizona. As a Doctoral Student in Educational Policy and Evaluation, his research focuses on policies affecting educational equity and issues of social justice - particularly those related to historically vulnerable, minority populations. 


\section{SPECIAL ISSUE Social Pedagogy in the $21^{\text {st }}$ Century education policy analysis archives}

\section{(c)}

SOMEFIIGHISRESERVED Readers are free to copy, display, and distribute this article, as long as the work is attributed to the author(s) and Education Policy Analysis Archives, it is distributed for noncommercial purposes only, and no alteration or transformation is made in the work. More details of this Creative Commons license are available at http://creativecommons.org/licenses/by-nc-sa/3.0/. All other uses must be approved by the author(s) or EPAA. EPAA is published by the Mary Lou Fulton Institute and Graduate School of Education at Arizona State University Articles are indexed in CIRC (Clasificación Integrada de Revistas Científicas, Spain), DIALNET (Spain), Directory of Open Access Journals, EBSCO Education Research Complete, ERIC, Education Full Text (H.W. Wilson), QUALIS A2 (Brazil), SCImago Journal Rank; SCOPUS, SOCOLAR (China).

Please contribute commentaries at http://epaa.info/wordpress/ and send errata notes to Gustavo E. Fischman fischman@asu.edu

Join EPAA's Facebook community at https://www.facebook.com/EPAAAAPE and Twitter feed@epaa_aape. 


\section{education policy analysis archives editorial board}

Editor Gustavo E. Fischman (Arizona State University)

Associate Editors: David R. Garcia (Arizona State University), Stephen Lawton (Arizona State University)

Rick Mintrop, (University of California, Berkeley) Jeanne M. Powers (Arizona State University)

Jessica Allen University of Colorado, Boulder

Gary Anderson New York University

Michael W. Apple University of Wisconsin, Madison

Angela Arzubiaga Arizona State University

David C. Berliner Arizona State University

Robert Bickel Marshall University

Henry Braun Boston College

Eric Camburn University of Wisconsin, Madison

Wendy C. Chi* University of Colorado, Boulder

Casey Cobb University of Connecticut

Arnold Danzig Arizona State University

Antonia Darder University of Illinois, UrbanaChampaign

Linda Darling-Hammond Stanford University

Chad d'Entremont Strategies for Children

John Diamond Harvard University

Tara Donahue Learning Point Associates

Sherman Dorn University of South Florida

Christopher Joseph Frey Bowling Green State University

Melissa Lynn Freeman* Adams State College

Amy Garrett Dikkers University of Minnesota

Gene V Glass Arizona State University

Ronald Glass University of California, Santa Cruz

Harvey Goldstein Bristol University

Jacob P. K. Gross Indiana University

Eric M. Haas WestEd

Kimberly Joy Howard* University of Southern California

Aimee Howley Ohio University

Craig Howley Ohio University

Steve Klees University of Maryland

Jaekyung Lee SUNY Buffalo
Christopher Lubienski University of Illinois, UrbanaChampaign

Sarah Lubienski University of Illinois, UrbanaChampaign

Samuel R. Lucas University of California, Berkeley

Maria Martinez-Coslo University of Texas, Arlington

William Mathis University of Colorado, Boulder

Tristan McCowan Institute of Education, London

Heinrich Mintrop University of California, Berkeley

Michele S. Moses University of Colorado, Boulder

Julianne Moss University of Melbourne

Sharon Nichols University of Texas, San Antonio

Noga O'Connor University of Iowa

João Paraskveva University of Massachusetts, Dartmouth

Laurence Parker University of Illinois, UrbanaChampaign

Susan L. Robertson Bristol University

John Rogers University of California, Los Angeles

A. G. Rud Purdue University

Felicia C. Sanders The Pennsylvania State University Janelle Scott University of California, Berkeley

Kimberly Scott Arizona State University

Dorothy Shipps Baruch College/CUNY

Maria Teresa Tatto Michigan State University

Larisa Warhol University of Connecticut

Cally Waite Social Science Research Council

John Weathers University of Colorado, Colorado Springs

Kevin Welner University of Colorado, Boulder

Ed Wiley University of Colorado, Boulder

Terrence G. Wiley Arizona State University

John Willinsky Stanford University

Kyo Yamashiro University of California, Los Angeles

* Members of the New Scholars Board 


\section{archivos analíticos de políticas educativas consejo editorial}

Editor: Gustavo E. Fischman (Arizona State University) Editores. Asociados Alejandro Canales (UNAM) y Jesús Romero Morante (Universidad de Cantabria)

Armando Alcántara Santuario Instituto de Investigaciones sobre la Universidad y la Educación, UNAM México

Claudio Almonacid Universidad Metropolitana de Ciencias de la Educación, Chile

Pilar Arnaiz Sánchez Universidad de Murcia, España

Xavier Besalú Costa Universitat de Girona, España Jose Joaquin Brunner Universidad Diego Portales, Chile

Damián Canales Sánchez Instituto Nacional para la Evaluación de la Educación, México

María Caridad García Universidad Católica del Norte, Chile

Raimundo Cuesta Fernández IES Fray Luis de León, España

Marco Antonio Delgado Fuentes Universidad Iberoamericana, México

Inés Dussel FLACSO, Argentina

Rafael Feito Alonso Universidad Complutense de Madrid, España

Pedro Flores Crespo Universidad Iberoamericana, México

Verónica García Martínez Universidad Juárez Autónoma de Tabasco, México

Francisco F. García Pérez Universidad de Sevilla, España

Edna Luna Serrano Universidad Autónoma de Baja California, México

Alma Maldonado Departamento de Investigaciones Educativas, Centro de Investigación y de Estudios Avanzados, México

Alejandro Márquez Jiménez Instituto de Investigaciones sobre la Universidad y la Educación, UNAM México

José Felipe Martínez Fernández University of California Los Angeles, USA
Fanni Muñoz Pontificia Universidad Católica de Perú

Imanol Ordorika Instituto de Investigaciones Economicas - UNAM, México

Maria Cristina Parra Sandoval Universidad de Zulia, Venezuela

Miguel A. Pereyra Universidad de Granada, España

Monica Pini Universidad Nacional de San Martín, Argentina

Paula Razquin UNESCO, Francia

Ignacio Rivas Flores Universidad de Málaga, España

Daniel Schugurensky Arizona State University

Orlando Pulido Chaves Universidad Pedagógica Nacional, Colombia

José Gregorio Rodríguez Universidad Nacional de Colombia

Miriam Rodríguez Vargas Universidad Autónoma de Tamaulipas, México

Mario Rueda Beltrán Instituto de Investigaciones sobre la Universidad y la Educación, UNAM México

José Luis San Fabián Maroto Universidad de Oviedo, España

Yengny Marisol Silva Laya Universidad Iberoamericana, México

Aida Terrón Bañuelos Universidad de Oviedo, España

Jurjo Torres Santomé Universidad de la Coruña, España

Antoni Verger Planells University of Amsterdam, Holanda

Mario Yapu Universidad Para la Investigación Estratégica, Bolivia 


\section{arquivos analíticos de políticas educativas conselho editorial}

Editor: Gustavo E. Fischman (Arizona State University)

Editores Associados: Rosa Maria Bueno Fisher e Luis A. Gandin

(Universidade Federal do Rio Grande do Sul)

Dalila Andrade de Oliveira Universidade Federal de Minas Gerais, Brasil

Paulo Carrano Universidade Federal Fluminense, Brasil

Alicia Maria Catalano de Bonamino Pontificia Universidade Católica-Rio, Brasil

Fabiana de Amorim Marcello Universidade Luterana do Brasil, Canoas, Brasil

Alexandre Fernandez Vaz Universidade Federal de Santa Catarina, Brasil

Gaudêncio Frigotto Universidade do Estado do Rio de Janeiro, Brasil

Alfredo M Gomes Universidade Federal de Pernambuco, Brasil

Petronilha Beatriz Gonçalves e Silva Universidade Federal de São Carlos, Brasil

Nadja Herman Pontificia Universidade Católica -Rio Grande do Sul, Brasil

José Machado Pais Instituto de Ciências Sociais da Universidade de Lisboa, Portugal

Wenceslao Machado de Oliveira Jr. Universidade Estadual de Campinas, Brasil
Jefferson Mainardes Universidade Estadual de Ponta Grossa, Brasil

Luciano Mendes de Faria Filho Universidade Federal de Minas Gerais, Brasil

Lia Raquel Moreira Oliveira Universidade do Minho, Portugal

Belmira Oliveira Bueno Universidade de São Paulo, Brasil

António Teodoro Universidade Lusófona, Portugal

Pia L. Wong California State University Sacramento, U.S.A

Sandra Regina Sales Universidade Federal Rural do Rio de Janeiro, Brasil

Elba Siqueira Sá Barreto Fundação Carlos Chagas, Brasil

Manuela Terrasêca Universidade do Porto, Portugal

Robert Verhine Universidade Federal da Bahia, Brasil

Antônio A. S. Zuin Universidade Federal de São Carlos, Brasil 